\title{
Corporate Governance Practice in Malaysian Budget Hotel and Accommodation Cooperatives
}

\author{
1Azlan Zainol Abidin, 2Nurhazani Mohd Shariff, 3Kamarul Bahrain Abdul Manaf, 4Mohamad Jais
}

${ }_{1}$ School of Languages, Civilization \& Philosophy, Universiti Utara Malaysia, 06010 Sintok, Kedah, Malaysia.

2School of Tourism, Hospitality \& Event Management, Universiti Utara Malaysia, 06010 Sintok, Kedah, Malaysia.

${ }_{3}$ Tunku Intan Safinaz School of Accounting, Universiti Utara Malaysia, 06010 Sintok, Kedah, Malaysia.

4Department of Accounting and Finance, Faculty of Economics and Business, Universiti Malaysia Sarawak, Malaysia.

Correspondence Author: Azlan Zainol Abidin, School of Languages, Civilization \& Philosophy, Universiti Utara Malaysia, 06010 Sintok, Kedah, Malaysia. E-mail:azlan@uum.edu.my

Received date: 22 December 2017, Accepted date: 22 January 2018, Online date: 5 February 2018

Copyright: (C) 2018 Azlan Zainol Abidin et al. This is an open-access article distributed under the terms of the Creative Commons Attribution License, which permits unrestricted use, distribution, and reproduction in any medium, provided the original author and source are credited.

\begin{abstract}
Corporate governance plays essential roles even in a small organization such as cooperative. However, none has studied in the context of Malaysian budget hotel and accommodation cooperatives. Since tourism and hospitality industry in Malaysia contributes to the country's economy, the government has expanded the roles of budget hotels and accommodation cooperatives within the sectors. The major purpose of this study is to investigate corporate governance practice in the Malaysian budget hotel and accommodation cooperatives based on the existing guidelines of cooperative governance. The findings indicated that corporate governance practice is important in the budget hotel and accommodation cooperatives. Nine domains of corporate governance practice significantly derived in line with the guidelines namely management, appointment, responsibilities and accountability, information, assessment, remuneration, auditing and control, communication and principles and values. The findings eventually contribute to the management of budget hotel and accommodation cooperatives as to sustain the economy and community wealth particularly within the tourism and hospitality industry.
\end{abstract}

Key words: Corporate governance, Cooperatives, Malaysian budget hotel accommodation

\section{INTRODUCTION}

Cooperative is defined by the International Co-operative Alliance (ICA) as 'an autonomous association of persons united voluntarily to meet their common economic, social and cultural needs and aspirations through a jointly-owned and democratically controlled enterprise' [11]. As noted by the National Cooperative Policy [17], cooperatives are also expected to become the third crucial engine after the public and privates sector in driving the Malaysian's economic growth. In June 2011, about 110 cooperatives out of 8,606 registered that year have been classified as the big cluster due to the returns received from their businesses reached almost RM5million per year [27].

Several studies have emphasized the essential roles of corporate governance in cooperatives. For instance, the success of cooperatives are found to have significant relationships with the structure of cooperative organization [12,21]. Further, the effectiveness of cooperative are also found to be significantly depend on the existence of pillars of good governance for instance participation, accountability and transparency [15,18]. Therefore, several researchers believe, to be sustainable as in to prevent fraud and mismanagement, good corporate governance practice is vital for cooperatives [7,22]. Additionally, Hashim, Zakaria and Ahmad Fawzi [9] emphasize that the strengths of cooperatives have also resulted from factors for instance members, share capital, organization, benefits and community involvement.

\section{Cooperatives Movement in Malaysia:}

The Malaysia Cooperative Commission (MCC) also known as Suruhanjaya Koperasi Malaysia [23] is responsible to monitor and regulate cooperative movements under the Ministry of Domestic Trade, Co-operatives and Consumerism. The cooperative legislation which has been governing cooperative movements is under the Cooperative Act 1948 and had been replaced by the Cooperative Act 1993 which states on the procedures of the registration, rights, privileges and other matters related to the cooperatives.

To further strengthen the law, the Cooperative Regulations 1995 was established which unifies and consolidates the various legislations. Additionally, the latest Cooperative Act 2007 (Act A1297) has been brought forth with the objective of promoting cooperative values of trustworthiness, transparency and honesty within the cooperative society development.

\subsection{Problem Statement of the Study:}

Good corporate governance provides positive influence and impacts not only on its owners/members but also to the whole community. Similarly, this is practiced by the budget hotels and accommodation cooperatives as to sustain and produce fusion between the economic and social development. Since tourism and hospitality industry in Malaysia also contributes to the country's economy and plays essential role to sustain the community wealth, the government has expand the roles of budget hotels and accommodation cooperatives within the sectors. 
It is noted that board characteristics have received much attention in the literature regarding corporate governance [1,20]. This is supported by a tentative framework developed in study conducted that having a long term plan for cooperative will influence the performance of cooperatives in Malaysia [25]. Moreover, a study conducted among the 250 board of directors of cooperatives in Malaysia also reveals that cooperative that has a strategic plan for at least 3 years significantly contribute towards the success of cooperatives [24].

Several previous studies also indicated a negative relationship between board size and firm performance [8,10,28]. Further, Adams and Mehran [1] and Dalton and Dalton [6] suggested that better performance is associated with large boards. Few studies have also emphasized the roles of Boards of Directors in cooperatives governance within the tourism and hospitality industry $[1,13]$. However, there has been no study concerning the budget hotel and accommodation cooperatives within the context of Malaysia.

\subsection{Objective of the Study:}

- To examine whether the Board of Directors aware of corporate governance practice in the budget hotel and accommodation cooperatives;

- To identify the major domains of corporate governance practice in the budget hotel and accommodation cooperatives; and

- To examine the most vital practice of corporate governance in the budget hotel and accommodation cooperatives.

3. Methodology:

30 budget hotel and accommodation cooperatives throughout Malaysia were selected as respondents for the study. They were identified according to the list provided by the SKM in the handbook of Budget Hotel and Accommodation Cooperatives. A survey questionnaire was used as a major instrument and distributed to the Board of Directors of the selected cooperatives via mail. 56 Board of Directors had returned the completed questionnaires which presented $31 \%$ of the population. The data was analyzed for descriptive analysis using Statistical Package for Social Sciences (SPSS).

The first section of the questionnaire asked the respondents to provide their profile backgrounds including their awareness on the corporate governance practice in cooperatives and also awareness of the existence of the guidelines. The next section consisted of 35 items with nine domains representing the corporate governance practice based on the guidelines of corporate governance for cooperatives.

\section{Findings of the Study:}

The findings indicated that majority of the respondents aware of the corporate governance practice in cooperatives (85.7\%) whilst only a small portion did not aware of the practice $(14.3 \%)$. Additionally, majority of them also aware of the existing guidelines $(82.1 \%)$ and only few did not aware of the guidelines $(17.9 \%)$.

Additionally, there are nine domains of corporate governance in cooperatives based on the cooperatives governance guideline (Table 1). The first domain namely MANAGEMENT, consisted of five managerial items followed by the second domain which is APPOINTMENT consisted of three practices and the third domain namely RESPONSIBILITIES AND ACCOUNTABILITY consisted of six practices Further, the fourth domain is namely INFORMATION consisted of three practices. The fifth domain which is ASSESSMENT consisted of six corporate governance practices. The sixth domain which is REMUNERATION consisted of three corporate governance practices. Additionally, the seventh domain of corporate governance in cooperatives namely AUDITING AND CONTROL consisted of three practices. Finally, the eighth domain which is COMMUNICATION and the ninth domain namely PRINCIPLE AND VALUES both consisted of three practices each.

\begin{tabular}{|c|c|}
\hline No. & MANAGEMENT \\
\hline 1 & Cooperative is governed by an effective Board. \\
\hline 2 & Cooperative has a clear mission. \\
\hline 3 & Cooperative has a clear strategy. \\
\hline 4 & Cooperative has a clear governance values. \\
\hline \multirow[t]{2}{*}{5} & Cooperative divides balanced responsibilities between the Board members. \\
\hline & APPOINTMENT \\
\hline 6 & The process of appointment of new members is carried out formally. \\
\hline 7 & The process of appointment of new members is carried out transparently. \\
\hline \multirow[t]{2}{*}{8} & Reappointment of members of the Board is set at an interval of at least every three years. \\
\hline & RESPONSIBILITIES AND ACCOUNTABILITY \\
\hline 9 & Members of the Board have appropriate skills. \\
\hline 10 & Members of the Board have appropriate experiences. \\
\hline 11 & Members of the Board are caliber in performing their duties. \\
\hline 12 & Members of the Board are capable of carrying out their duties. \\
\hline 13 & Members of the Board have integrity in performing their duties. \\
\hline \multirow[t]{2}{*}{14} & Members of the Board focus and commit to the cooperative. \\
\hline & INFORMATION \\
\hline 15 & The management provides complete information to the Board during the meeting. \\
\hline 16 & The management provides accurate information to the Board during the meeting. \\
\hline \multirow[t]{2}{*}{17} & The management provides up-to-date information to the Board during the meeting. \\
\hline & ASSESSMENT \\
\hline 18 & The Board makes official assessment on the overall effectiveness of the members of the Board. \\
\hline 19 & The Board makes official assessment on the overall effectiveness of the Board. \\
\hline 20 & The Board makes official assessment on the overall effectiveness of the Chief Executive Officer. \\
\hline 21 & The Board makes continuous assessment on the overall effectiveness of the Board. \\
\hline 22 & The Board makes continuous assessment on the overall effectiveness of the members of the Board. \\
\hline \multirow[t]{2}{*}{23} & The Board makes continous assessment on the overall effectiveness of the Chief Executive Officer. \\
\hline & REMUNERATION \\
\hline 24 & Procedure for determining the remuneration package is formally carried out. \\
\hline 25 & Procedure for determining the remuneration package is transparently carried out. \\
\hline \multirow[t]{2}{*}{26} & $\begin{array}{l}\text { Policies and practices in rewarding remuneration are implemented through an approach consistent with the culture, objectives, direction } \\
\text { and performance. }\end{array}$ \\
\hline & AUDITING AND CONTROL \\
\hline 27 & Cooperative always avoid a situation of conflict of interest. \\
\hline 28 & Cooperative implements robust auditing requirements. \\
\hline \multirow[t]{2}{*}{29} & Cooperative maintains an objective and professional relationship among auditors, members of the Board and the management. \\
\hline & COMMUNICATION \\
\hline 30 & Cooperative practices effective communication with members and stakeholders. \\
\hline 31 & Cooperative practices open communication with employees and stakeholders. \\
\hline
\end{tabular}


Citation: Azlan Zainol Abidin, Nurhazani Mohd Shariff, Kamarul Bahrain Abdul Manaf, Mohamad Jais, 2018. Corporate Governance Practice in Malaysian Budget Hotel and Accommodation Cooperatives. Advances in Natural and Applied Sciences., 12(1): 19-22.

\begin{tabular}{|l|l|}
\hline 32 & Cooperative practices effective risk management. \\
\hline & PRINCIPLES AND VALUES \\
\hline 33 & Cooperative governance is strong as it is operated transparently. \\
\hline 34 & Cooperative affairs are managed with the principles and values of a cooperative. \\
\hline 35 & Cooperative performance is evaluated based on the achievement of the level of member's satisfaction towards quality and service. \\
\hline
\end{tabular}

Further, the findings generally indicated that respondents positively perceived all the 35 corporate governance practices as vital practice in cooperatives with average mean value above 3.0. 'Policies and practices in rewarding remuneration are implemented through an approach consistent with the culture, objectives, direction and performance of the cooperative' derived as the most vital corporate governance practice positively perceived by the respondents $(m=4.75)$. Additionally, 'The Board makes official assessment on the overall effectiveness of the Board' derived as the least corporate governance item positively perceived by the respondents.

\section{Discussion:}

This section discusses the findings according to the three specified objectives.

5.1 To examine whether the Board of Directors aware of corporate governance practice in the budget hotel and accommodation cooperatives:

The findings from the analysis indicated that the Board of Directors aware of the existing corporate governance practice in the budget hotel and accommodation cooperatives. In fact, the findings also highlighted that they also aware the corporate governance practices have been applied in their budget hotel and accommodation cooperatives specifically in terms of managing the cooperatives.

The findings are significance to previous studies conducted by Chen [3] and Proenca and Soukiazis [19]. Further, the findings are also in line with other studies in the tourism and hospitality for instance Adams et al. [1] and Iwasaki [13]. Based on the findings, it is also noted that previous studies have confirmed that corporate governance determines the performance of the cooperatives. In fact it has been proven that there is a relationship between corporate governance and performance $[7,13,21]$.

\subsection{To identify the major domains of corporate governance practice in the budget hotel and accommodation cooperatives:}

The findings from the descriptive analysis indicated that the Board of Directors agreed all 35 items of corporate governance have been practiced in the budget hotel and accommodation cooperatives. Corporate governance practice for instance accountability, transparency and disclosure, responsibility, business ethics and corporate social responsibility are considered as important practices by the Board of Directors. The findings significantly in line with other studies such as Tan and Selvarani [26] and Keat and Young [14].

The Board of Directors also noted these domains as importance corporate governance practices which determine the performance of the budget hotel and accommodation cooperatives as in previous studies (Cornforth, 2004 and Cuevas and Fischer, 2006). Further the Board of Directors also agreed that the budget hotel and accommodation cooperatives have strong principles and values on the practices which eventually lead to trust and loyalty among the members as what has been suggested by Malo and Vezina [16].

\subsection{To examine the most vital practice of corporate governance in the budget hotel and accommodation cooperatives:}

The findings emphasized that policy and practices in rewarding remuneration to the members as the most vital practice of corporate governance in the budget hotel and accommodation cooperatives. This significantly indicated that the Board of Directors really concerned about the members wealth and benefits that they should receive. The Board of Directors of the budget hotel and accommodation cooperatives also agreed that the practices are vital in managing the cooperatives in order maintain high performance particularly to the social well-being and wealth of the community they represented.

\section{Conclusion:}

The findings of the study eventually contribute to the management of budget hotel and accommodation cooperatives in terms of practicing the corporate governance values. This would significantly strengthen the board members cohesiveness and also providing them with validated knowledge to survive since the ability of the cooperatives depend on the strong relationship among members, leaders within the cooperatives movement. The Board of Directors are also optimistic and confident to face contemporary business challenges within the environments. This would assist them in developing better structure, systems and strategies which may allow the budget hotel and accommodation cooperatives to build their strength and bring lasting benefits not just to the members but to the whole community as well.

Thus, it is vital for them to have adequate planning and encourage the participation from its members in their administration so as to boost the economics of the country and further promoting job creations as a strategy in reducing poverty. It is also recommended that the study to be further explored in terms of the relationships between the corporate governance practice and the performance of budget hotel and accommodation cooperatives to strengthen the management of the cooperatives.

\section{ACKNOWLEDGEMENT}

This paper is part of a research funded by Universiti Utara Malaysia.

\section{REFERENCES}

[1] Adams, R.B., B.E. Hermalin and M.S. Weisbach, 2010. The role of boards of directors in corporate governance: a conceptual framework and survey. Journal of Economic Literature, 48(1): 58-107.

[2] Adams, R.B. and H. Mehran, 2005. Corporate performance, board structure and its determinants in the banking industry. Paper presented at EFA 2005 Moscow Meetings. Available at SSRN http://ssrn.com/abstract1/4302593.

[3] Chen, M.H., 2010. The economy, tourism growth and corporate performance in the Taiwanese hotel industry. Tourism Management, 31(5): 665-675.

[4] Cornforth, C., 2004. The governance of cooperatives and mutual associations: A paradox perspectives. Annals of Public and Cooperative Economics, 75(1): 11-32.

[5] Cuevas, C and K. Fischer, 2006. Cooperative financial institutions: Issues in governance, regulation and supervision, World Bank Working, 82.

[6] Dalton, C.M. and D.R. Dalton, 2005. Boards of directors: Utilizing empirical evidence in developing practical prescriptions. British Journal of Management, 16(1): 91-97.

[7] Dayanandan, R., 2013. Good governance practice for better performance of community or organizations - myths and realities!!. Journal of Power, Politics \& Governance, 1(1): 10-26.

[8] Haniffa, R and M. Hudaib, 2006. Corporate governance structure and performance of Malaysian listed companies. Journal of Business Finance \& Accounting, 33: 1034-1062.

[9] Hashim, M.K., M. Zakaria and D. Ahmad Fawzi, 2014. Cooperatives in Malaysia: Their strengths, weaknesses, opportunities and threats. Paper presented at the 5th International conference on business and economic research (5th ICBER 2014).

[10] Hermalin, B.E. and M.S. Weisbach, 2003. Boards of directors as an endogenously determined institution: A survey of the economic literature. Federal Reserve Bank of New York Economic Policy Review, 9(1): 7-26.

[11] ICA - International Cooperative Alliance, 2009. Information on cooperatives. Retrieved from http://www.ica.coop/coop/index.html, 17 January. 
[12] Imran, S.C., M. Shahnawaz, N.K. Khurram and R. Sohail, 2009. Factors affecting good governance in Pakistan: An empirical analysis. European Journal of Scientific Research, 35(3): 337-346.

[13] Iwasaki, I., 2008. The determinants of board composition in a transforming economy: Evidence from Russia. Journal of Corporate Finance, 14(5): 532-549.

[14] Keat, P.G. and P.K.Y. Young, 2003. Managerial Economics (4th ed.), pp: 30-32. New Jersey: Prentice Hall.

[15] Mahazril Aini Ya, H.A.K. Hafizah and Y. Zuraini, 2012. Factors affecting cooperatives' performance in relation to strategic planning and members' participation. Procedia - Social and Behavioral Sciences, 65: 100-105.

[16] Malo, M and Vezina, 2004. Governance and management of collective user-based enterprises: Value-creation strategies and organizational configurations. Annals of Public and Co-operative Economics, 75(1): 113-137.

[17] National Co-operative Policy (NCP 2011-2020) (2002). Suruhan Jaya Koperasi Malaysia, Kuala Lumpur.

[18] Othman, I.W., M. Mohamad and A. Abdullah, 2013. Cooperative movements in Malaysia: The issue of governance. International Journal of Social, Management, Economics and Business Engineering, 7(6): 659-663.

[19] Proenca, S and E. Soukiazis, 2008. Tourism as an economic growth factor: a case study for Southern European countries. Tourism Economics, 14(4): 791806 .

[20] Raheja, C.G., 2005. Determinants of board size and composition: A theory of corporate boards. Journal of Financial and Quantitative Analysis, 40: 283-30.

[21] Salvosa, C.R., 2007. Bridging the governance divide in the Philippines: Perspectives from the cooperative sector. Dissertation submitted to the University of the Philippines- National College of Public Administration and Governance, Diliman, Quezon City.

[22] Shaarani, A.F., A. Ashaari, H.A. Hassan, S. Abdullah and R. Mohd Roslin, 2013. Financial support for cooperatives' businesses in Malaysia: Evidence of impact. International Journal of Innovations in Business, 2(5): 509-528.

[23] Suruhanjaya Koperasi Malaysia (SKM). 2012. Economic report cooperative sector 2010. Suruhanjaya Koperasi Malaysia.

[24] Sushila Devi, R., N. Nurizah, A.S. Mohd Shahron, J. Rafedah and M.H. Farahaini, 2010. Success factors of cooperatives in Malaysia: An exploratory investigation. Malaysian Journal of Co-operative Studies, 6: 1-24.

[25] Sushila Devi, R., N. Nurizah, A.S. Mohd Shahron, J. Rafedah and M.H. Farahaini, 2009. Factors influencing the performance of cooperatives in Malaysia: A tentative framework. Malaysian Journal of Co-operative Management, 5: 43-62.

[26] Tan, C.C. and P. Selvarani, 2008. Coping with cooperatives. New Sunday Times.

[27] Utusan Malaysia, 2012. Penjana Ekonomi Negara. July, 15. http://ww1.utusan.com.my/utusan/rencana/20120715/re_01/penjana-ekonomi-negara

[28] Yermack, D., 1996. Higher market valuation of companies with a small board of directors. Journal of Financial Economics, 40(2): 185-211. 